\title{
Positive responses of benthic macroinvertebrates to spatial and temporal reductions in water pollution downstream from a trout farm outlet
}

\author{
Julio A. Camargo* \\ Unidad Docente de Ecología, Departamento de Ciencias de la Vida, Universidad de Alcalá, 28805 Alcalá de Henares (Madrid), Spain
}

\begin{abstract}
Inland trout farms can cause important adverse effects on freshwater communities due to the discharge of wastewater effluents into recipient rivers. In this research, responses of benthic macroinvertebrates to diminished water pollution downstream from a trout farm outlet were examined at spatial and temporal scales. Field studies were carried out in the Upper Tajuña River (Central Spain) during the springs of 2007 and 2015. Water pollution decreased, with increasing the downstream distance from the trout farm effluent, and also from 2007 to 2015 as a likely consequence of the lowered annual production of farmed rainbow trout following the 2008 economic recession. Reductions in water pollution resulted in increased concentrations of dissolved oxygen and decreased levels of turbidity and inorganic nutrients (ammonia and phosphate). Benthic macroinvertebrates responded positively to diminished water pollution by decreasing the relative abundance of collector-gatherers (oligochaetes and chironomids) and increasing the relative abundance of shredders and scrapers (ephemeropterans, plecopterans and trichopterans). In addition, values of taxonomic diversity and Biological Monitoring Water Quality biotic indices tended to increase. It is concluded that the wastewater treatment system of the trout farm should be improved to minimize the environmental impact on the recipient river.
\end{abstract}

Keywords: trout farm / water pollution / macroinvertebrate responses

Résumé - Réponses positives des macroinvertébrés benthiques aux réductions spatiales et temporelles de la pollution de l'eau en aval d'un élevage de truites. Les fermes de truites peuvent avoir des effets négatifs sur les communautés d'eau douce en raison du rejet de leurs effluents d'eaux usées dans les rivières récepteurs. Dans cette recherche, les réactions des macroinvertébrés benthiques à la diminution de la pollution de l'eau en aval d'un effluent de ferme à truites ont été examinées à une échelle spatiale et à une échelle temporelle. Des études sur le terrain ont été réalisées dans la Rivière Tajuna (centre de l'Espagne) au cours des printemps 2007 et 2015. La pollution de l'eau a diminué avec l'augmentation de la distance en aval de l'effluent de la ferme à truites, et également de 2007 à 2015, conséquence probable de la baisse de la production annuelle de truites arc-en-ciel d'élevage après la récession économique de 2008. La réduction de la pollution de l'eau ont entraîné principalement une augmentation des concentrations d'oxygène dissous et une diminution des niveaux de turbidité et de nutriments inorganiques (ammoniac et phosphate). Les macroinvertébrés benthiques ont réagi positivement à la réduction de la pollution de l'eau, en diminuant l'abondance relative des mangeurs de sédiments fins (oligochètes et chironomides) et en augmentant l'abondance relative des broyeurs et des racleurs de substrat (éphéméroptères, plécoptères et trichoptères). En outre, les valeurs de diversité taxonomique et des indices biotiques de surveillance biologique de la qualité de l'eau avaient tendance à augmenter. Il est conclu que le système de traitement des eaux usées de la ferme de truites devrait être amélioré afin de minimiser l'impact environnemental sur la rivière récepteur.

Mots clés : ferme de truites / pollution de l'eau / réponses des macroinvertébrés

\footnotetext{
*Corresponding author: julio.camargo@uah.es
} 


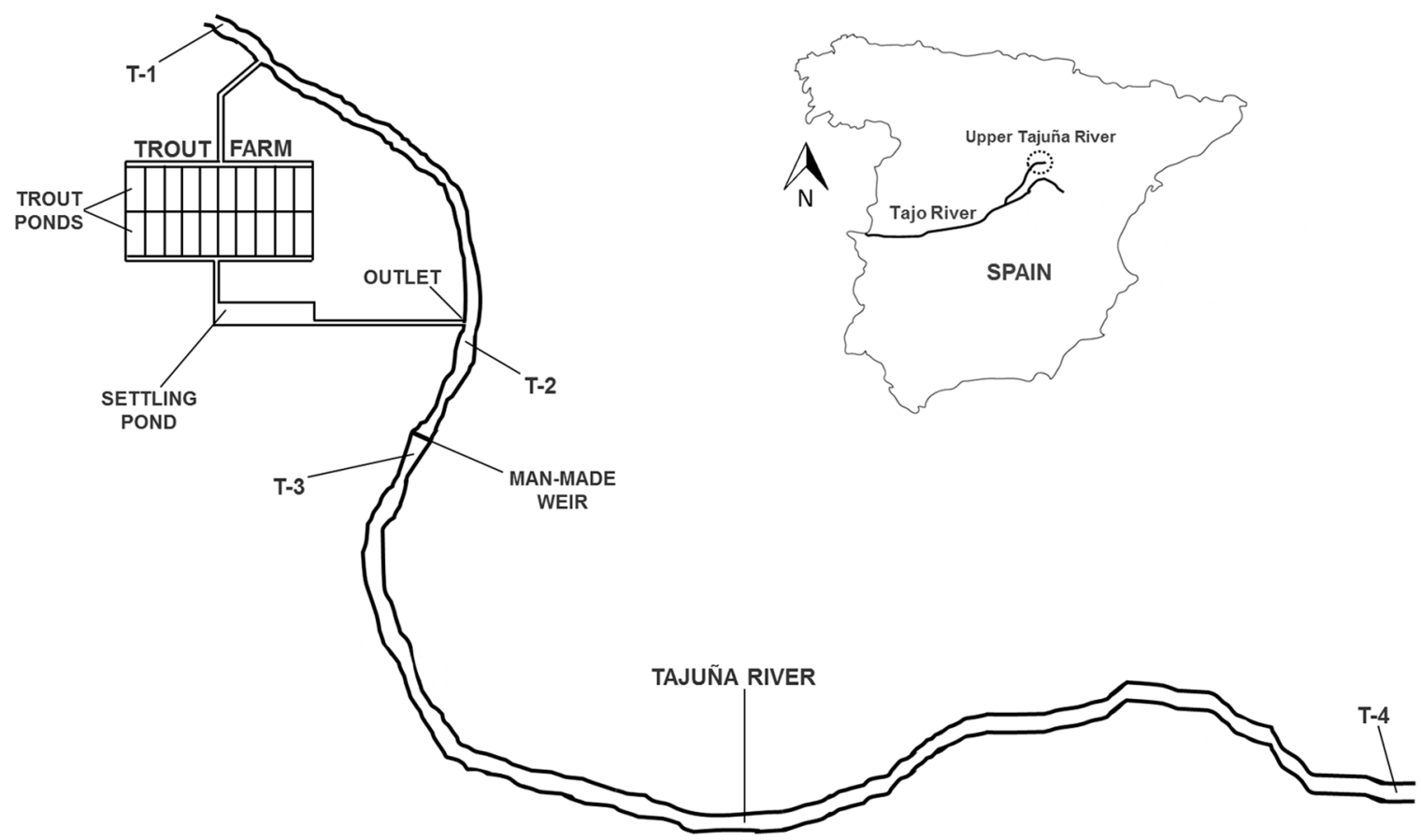

Fig. 1. General diagram of the flow-through trout farm, showing the location of sampling sites (T-1, T-2, T-3 and T-4) in the Upper Tajuña River (Tajo River Basin, Central Spain).

\section{Introduction}

The aquaculture of rainbow trout has developed across the world, thanks mainly to the use of manufactured fish feeds that have improved the efficiency of trout farming production (Food And Agicultural Organization of the United Nations, 2016). Nonetheless, despite the benefits of the aquaculture of rainbow trout to mankind, inland trout farms can cause important adverse effects on freshwater communities, owing to the discharge of wastewater effluents into recipient rivers and the ensuing changes in river environmental conditions downstream from trout farm outlets. Even in the case of inland trout farms, using conventional wastewater treatment techniques such as filtration, flocculation and/or sedimentation (the most economical and extended procedure for the accumulation of sludge), some degree of water pollution are expected to occur (MacMillan et al., 2003; Sindilariu, 2007; Tello et al., 2010).

Characteristic physicochemical alterations downstream from trout farm effluents involve decreases in dissolved oxygen concentrations, increases in nutrient (ammonia and phosphate, primarily) and turbidity (suspended solids) levels, and deposition of suspended solids on the river bottom (Boaventura et al., 1997; Bartoli et al., 2007; Ruiz-Zarzuela et al., 2009; Lalonde et al., 2015). Although biological alterations have been less studied, an increase in the abundance of primary producers is expected to occur as a consequence of nutrient enrichment (Carr and Goulder, 1990; Villanueva et al., 2000). Regarding aquatic animals, benthic macroinvertebrates can be adversely affected because of reductions in dissolved oxygen concentrations and the sedimentation of suspended solids (Roberts et al., 2009; Webb, 2012; Minoo et al., 2016). In addition, relatively high levels of unionized ammonia $\left(\mathrm{NH}_{3}\right)$ could cause toxicity to sensitive freshwater invertebrates (US Environmental Protection Agency, 2013).

In Spain, there are currently 94 rainbows trout farms that constitute the most important inland aquaculture industry (Ministerio de Agricultura, Pesca y Alimentación, 2018). Many of these trout farms are located in the upper reaches of river systems, where unpolluted fresh waters naturally exhibit high levels of dissolved oxygen and relatively low temperatures. However, the Spain's annual production of farmed rainbow trout has significantly decreased following the 2008 economic recession, dropping from 28416 tonnes in 2007 to 9515 tonnes in 2015 (Ministerio de Agricultura, Pesca y Alimentación, 2018).

The main goal of this investigation was to assess responses of benthic macroinvertebrates to spatial and temporal reductions in water pollution downstream from a trout farm outlet. To achieve this goal, field studies were carried out along the study area in 2015, to subsequently compare the obtained results with physicochemical and biological data from field studies carried out in 2007. Although raw data from 2007 field studies were previously used in a 2006-2007 composite research (Camargo et al., 2011), they have never been published before.

\section{The study area and sampling sites}

Field studies were conducted in the Upper Tajuña River, a limestone river within the Tajo River Basin (Fig. 1). The Tajuña River originates in the Solorio Range (province of Guadalajara), at an elevation of $1244 \mathrm{~m}$, flowing through $225 \mathrm{~km}$ before joining the Jarama River (province of Madrid), which in turn is a tributary of the Tajo River. Like many other rivers in Central Spain, the natural flow regime of the Tajuña 
River is characterized by higher flows during the winter and spring and minimum flows at the end of the summer.

A flow-through trout farm is situated about $13 \mathrm{~km}$ downstream from the river source. Its production of farmed rainbow trout is mainly based on the use of extruded pellets as artificial diet. This production, however, declined following the 2008 economic recession, passing from about 35 tonnes in 2007 (Camargo et al., 2011) to less than the half in 2015. Wastewater treatment involves simple sedimentation in a small settling pond without the addition of chemicals (Fig. 1). The settling pond was almost full in 2007 , exhibiting a much lower amount of accumulated sludge in 2015 (personal observation). Estimated river flows upstream from the trout farm in the springs of 2007 and 2015 were 0.411 and $0.395 \mathrm{~m}^{3} / \mathrm{s}$, respectively.

Four sampling sites were selected along the study area (Fig. 1): T-1 was placed upstream from the trout farm, being used as a reference station; T-2, T-3 and T- 4 were placed about 10,100 and $1000 \mathrm{~m}$ downstream from the trout farm effluent, respectively. The river bottom was basically stony with cobbles and pebbles at T-1, T-3 and T-4, but it was covered by a relatively thick layer of organic sediment at $\mathrm{T}-2$. This fact was facilitated by the existence of a man-made weir of about $1 \mathrm{~m}$ high upstream from T-3 (Fig. 1). The small dam was constructed with branches and logs, rocks, and sandbags, reducing the river flow velocity and reinforcing the sedimentation of suspended solids (particularly derived from the trout farm effluent) at T-2. The riverbed was $2-3 \mathrm{~m}$ wide along the study area.

\section{Materials and methods}

\subsection{Water sampling and analyses}

Sampling surveys to analyse river water properties were carried out during the springs of 2007 and 2015. Water velocity, temperature, $\mathrm{pH}$, conductivity, and dissolved oxygen were measured in situ according to standard methods (American Public Health Association, 1998). In addition, water samples for analysing turbidity and inorganic nutrients (phosphate and total ammonia) were collected using clean polyethylene containers, chilled to $1-4{ }^{\circ} \mathrm{C}$ in the dark, and transported to laboratory within 24 hours. In the laboratory, turbidity was directly analysed with a standard turbidimeter. To analyse inorganic nutrients, water samples were first filtered through pre-rinsed $0.45 \mu \mathrm{m}$ cellulose acetate filters, and then water filtrates were used to determine concentrations of $\mathrm{PO}_{4}-\mathrm{P}$ and $\mathrm{NH}_{4}-\mathrm{N}$ by spectrophotometry (American Public Health Association, 1998). Because unionized ammonia $\left(\mathrm{NH}_{3}\right)$ is much more toxic to aquatic animals than ionized ammonia $\left(\mathrm{NH}_{4}{ }^{+}\right.$) (US Environmental Protection Agency, 2013), $\mathrm{NH}_{3}$ concentrations were also estimated on the basis of total ammonia concentrations and values of water temperature and $\mathrm{pH}$ in accordance with Emerson et al.'s (1975) formulas.

\subsection{Macroinvertebrate sampling and analyses}

Sampling surveys of benthic macoinvertebrates were also carried out in 2007 and 2015, following water sampling and analyses. To sample benthic macroinvertebrates, a Surber bottom sampler (Hauer and Lamberti, 1996), which enclosed a sampling area of $0.09 \mathrm{~m}^{2}$ and was equipped with capturing net with a mesh size of $250 \mu \mathrm{m}$, was used to take three riffle bottom samples at each sampling site on each sampling survey. All samples were preserved in $4 \%$ formalin until laboratory analyses. Macroinvertebrates were identified and counted using a light stereomicroscope. Taxonomic identification was basically carried out to the family level in accordance with Tachet et al. (2003). This family level has been often selected for practical biomonitoring of freshwater pollution and habitat degradation with benthic macroinvertebrates (Armitage et al., 1983; Rosenberg and Resh, 1993; Camargo et al., 2004; Ziglio et al., 2006; Alvial et al., 2012; Gartzia et al., 2015). After identification and counting, macroinvertebrate samples were dried in an oven at $60^{\circ} \mathrm{C}$ for 24 hours in order to estimate total biomass (dry-weight).

\subsection{Biological metrics and indices}

Abundance and diversity metrics were estimated for the whole macroinvertebrate community: macroinvertebrate abundance is expressed as the total density (number of individuals) per sampling unit (Surber sampler), and as the total biomass (dry-weight) per sampling unit; macroinvertebrate diversity or richness is expressed as the total number of families per sampling unit. Additionally, the abundance percentage of oligochaetes and chironomids $(\mathrm{OC} \%)$, and the abundance percentage of ephemeropterans, plecopterans and trichopterans (EPT\%) were estimated. Significant changes in the value of these metrics can indicate environmental disturbances, including freshwater pollution and habitat degradation (Hellawell, 1986; Rosenberg and Resh, 1993; Camargo et al., 2004; Ziglio et al., 2006; Odume et al., 2012; Minoo et al., 2016).

The Biological Monitoring Water Quality score system (BMWQ; Camargo, 1993) was also applied to assess freshwater quality in ecological terms. This score system is based on the tolerance of macroinvertebrate families to freshwater pollution (organic pollution and nutrient enrichment, particularly) in rivers and streams of the Iberian Peninsula (Camargo, 1993). The total-BMWQ score ( $t$ BMWQ) and the average-BMWQ score ( $a$-BMWQ) were calculated: $t$-BMWQ is estimated by summing the individual scores of all families present at a sampling site, and can take values between 1 (very poor water quality) and $>200$ (excellent water quality); $a$-BMWQ is estimated by dividing the value of $t$-BMWQ by the number of families, and can take values between 1 (very poor water quality) and $>12$ (excellent water quality).

Lastly, to examine changes in the trophic structure of the macroinvertebrate community at each sampling site on each sampling survey, benthic macroinvertebrates were allocated to five functional feeding groups in accordance with Tachet et al. (2003) and Thorp and Covich (2010): shredders basically feed on coarse particulate organic matter; scrapers mainly feed on periphyton and perilithon; collector-gatherers feed on fine organic detritus, but many of them can also feed on periphyton and perilithon; collector-filterers mainly feed on organic material suspended in the water column; and predators feed on animal preys. Relative contributions (\%) of functional feeding groups to the macroinvertebrate community were calculated on the basis of density estimates. 
Table 1. Mean ( $n=3-12)$ values of water physicochemical parameters at sampling sites (T-1, T-2, T-3 and T-4) in the 2007 and 2015 sampling surveys.

\begin{tabular}{|c|c|c|c|c|c|c|c|c|}
\hline & \multicolumn{2}{|c|}{$\mathrm{T}-1$} & \multicolumn{2}{|c|}{ T-2 } & \multicolumn{2}{|c|}{$\mathrm{T}-3$} & \multicolumn{2}{|c|}{$\mathrm{T}-4$} \\
\hline & 2007 & 2015 & 2007 & 2015 & 2007 & 2015 & 2007 & 2015 \\
\hline Water velocity $(\mathrm{cm} / \mathrm{s})$ & 23.5 & 22.8 & $17.3^{\mathrm{a}}$ & $16.5^{\mathrm{a}}$ & 22.0 & 21.7 & 23.1 & 21.9 \\
\hline Temperature $\left({ }^{\circ} \mathrm{C}\right)$ & 13.3 & 13.7 & 12.8 & 13.2 & 12.9 & 13.2 & 13.0 & 13.4 \\
\hline $\mathrm{pH}$ & 8.3 & 8.2 & $7.9^{\mathrm{a}}$ & 8.1 & $8.0^{\mathrm{a}}$ & 8.2 & 8.1 & 8.2 \\
\hline Conductivity $(\mu \mathrm{S} / \mathrm{cm})$ & $631.7^{\mathrm{b}}$ & $684.2^{\mathrm{b}}$ & $705.0^{\mathrm{a}}$ & 698.5 & $704.2^{\mathrm{a}}$ & 697.3 & $730.8^{\mathrm{a}}$ & 719.5 \\
\hline Dissolved oxygen $\left(\mathrm{mg} \mathrm{O}_{2} / \mathrm{L}\right)$ & 9.5 & 9.8 & $4.3^{\mathrm{a}, \mathrm{b}}$ & $6.0^{\mathrm{a}, \mathrm{b}}$ & $6.1^{\mathrm{a}, \mathrm{b}}$ & $7.4^{\mathrm{a}, \mathrm{b}}$ & $7.2^{\mathrm{a}, \mathrm{b}}$ & $8.6^{\mathrm{a}, \mathrm{b}}$ \\
\hline Total ammonia $\left(\mu \mathrm{g} \mathrm{NH} \mathrm{N}_{4}-\mathrm{N} / \mathrm{L}\right)$ & $76.7^{\mathrm{b}}$ & $53.3^{\mathrm{b}}$ & $687.0^{\mathrm{a}, \mathrm{b}}$ & $240.0^{\mathrm{a}, \mathrm{b}}$ & $590.0^{\mathrm{a}, \mathrm{b}}$ & $176.7^{\mathrm{a}, \mathrm{b}}$ & $464.0^{\mathrm{a}, \mathrm{b}}$ & $110.0^{\mathrm{a}, \mathrm{b}}$ \\
\hline Unionized ammonia $(\mu \mathrm{g} \mathrm{NH}-\mathrm{N} / \mathrm{L})$ & 2.7 & 2.4 & $15.5^{\mathrm{a}, \mathrm{b}}$ & $6.9^{\mathrm{a}, \mathrm{b}}$ & $16.8^{\mathrm{a}, \mathrm{b}}$ & $6.3^{\mathrm{a}, \mathrm{b}}$ & $16.3^{\mathrm{a}, \mathrm{b}}$ & $4.5^{\mathrm{a}, \mathrm{b}}$ \\
\hline Phosphate $\left(\mu \mathrm{g} \mathrm{PO}_{4}-\mathrm{P} / \mathrm{L}\right)$ & 70.0 & 60.0 & $256.7^{\mathrm{a}, \mathrm{b}}$ & $153.3^{\mathrm{a}, \mathrm{b}}$ & $230.0^{\mathrm{a}, \mathrm{b}}$ & $106.7^{\mathrm{a}, \mathrm{b}}$ & $160.0^{\mathrm{a}, \mathrm{b}}$ & $83.3^{\mathrm{a}, \mathrm{b}}$ \\
\hline Turbidity (NTU) & 0.7 & 0.9 & $5.1^{\mathrm{a}, \mathrm{b}}$ & $2.6^{\mathrm{a}, \mathrm{b}}$ & $2.4^{\mathrm{a}, \mathrm{b}}$ & $1.2^{\mathrm{b}}$ & $1.8^{\mathrm{a}, \mathrm{b}}$ & $1.0^{\mathrm{b}}$ \\
\hline
\end{tabular}

${ }^{\mathrm{a}}$ Significant $(P<0.01)$ differences between the reference station $(\mathrm{T}-1)$ and polluted sampling sites $(\mathrm{T}-2, \mathrm{~T}-3$ and T-4) on each sampling survey are indicated with the letter a.

${ }^{\mathrm{b}}$ Significant $(P<0.01)$ differences between sampling surveys at each sampling site are indicated with the letter $\mathrm{b}$.

\subsection{Statistical analyses}

Because parametric methods usually have more statistical power than nonparametric methods for detecting that the null hypothesis is false (Sokal and Rohlf, 1995), $t$-tests were performed to check for significant $(P<0.01)$ differences between sampling sites and between sampling surveys: on one hand, for each sampling survey, I compared mean values of water physicochemical parameters and biological metrics and indices at the reference station (T-1) with mean values at each polluted sampling site (T-2, T-3 and T-4); on the other hand, for each sampling site, I compared mean values of water physicochemical parameters and biological metrics and indices in the 2007 sampling survey with mean values in the 2015 sampling survey. Besides, the relation between physicochemical parameters and biological metrics and indices was examined by Pearson's correlation analysis. Owing to the relatively low number of measures, normality and homoscedasticity of data were assumed for physicochemical and biological data (Sokal and Rohlf, 1995).

\section{Results}

Mean values of water physicochemical parameters at each sampling site on each sampling survey are presented in Table 1. In the 2007 sampling survey, differences between the reference station (T-1) and polluted sampling sites (T-2, T-3 and T-4) were significant $(P<0.01)$ for $\mathrm{pH}$, conductivity, dissolved oxygen, ammonia, phosphate and turbidity, with mean values of $\mathrm{pH}$ and dissolved oxygen being lower, and mean values of conductivity, turbidity and inorganic nutrients being higher, downstream from the trout farm effluent (Tab. 1). Furthermore, mean values of $\mathrm{pH}$, conductivity and dissolved oxygen tended to increase with the downstream distance from the trout farm effluent, whereas values of turbidity, phosphate and ammonia tended to decrease (Tab. 1). Likewise, in the 2015 sampling survey, differences between the reference station and polluted sampling sites were significant $(P<0.01)$ for dissolved oxygen, ammonia, phosphate and turbidity (but not for $\mathrm{pH}$ and conductivity), with the spatial variation of these physicochemical parameters downstream from the trout farm outlet being similar to that observed in 2007 (Tab. 1). Nevertheless, at each polluted sampling site, mean values of dissolved oxygen were significantly $(P<0.01)$ higher in 2015 than in 2007, and mean values of ammonia, phosphate and turbidity were significantly $(P<0.01)$ lower in 2015 than in 2007 (Tab. 1). Indeed, estimated concentrations of unionized ammonia in the 2007 sampling survey were able to exceed water quality thresholds for the protection of sensitive freshwater animals during long-term exposures (US Environmental Protection Agency, 2013). On the other hand, in both sampling surveys, mean values of water velocity were significantly $(P<0.01)$ lower at T-2 than at T-1 (Tab. 1), this fact reinforcing the sedimentation of suspended solids at T-2.

Mean values of metrics and indices based on the community of benthic macroinvertebrates at each sampling site on each sampling survey are presented in Table 2. In the 2007 and 2015 sampling surveys, mean values of macroinvertebrate diversity, EPT\% and BMWQ biotic indices significantly $(P<0.01)$ decreased downstream from the trout farm outlet, particularly at T-2, but with a clear tendency to increase with the downstream distance from the trout farm effluent (Tab. 2). Conversely, mean values of $\mathrm{OC} \%$ significantly $(P<0.01)$ increased downstream from the trout farm outlet, particularly at T-2, but with a clear tendency to decrease with the downstream distance from the trout farm effluent (Tab. 2). Additionally, in both sampling surveys, macroinvertebrate abundance (density and biomass) significantly $(P<0.01)$ increased downstream from the trout farm outlet, exhibiting the highest mean values at the farthest sampling site (Tab. 2).

In general, Plannariidae flatworms, Hydrobiidae snails, Gammaridae amphipods, Baetidae and Heptageniidae ephemeropterans, Perlidae, Perlodidae and Leuctridae plecopterans, Calopterygidae dragonflies, Elmidae coleopterans, and Glossosomatidae and Sericostomatidae caddisflies appeared to be the macroinvertebrate families most adversely affected by the trout farm effluent. By contrast, oligochaetes, leeches, Planorbidae snails, Sphaeriidae bivalves, and Chironomidae and Ceratopogonidae dipterans were the macroinvertebrate families most favourably affected. Nonetheless, 
Table 2. Mean $(n=3)$ values of biological metrics and indices at sampling sites (T-1, T-2, T-3 and T-4) in the 2007 and 2015 sampling surveys.

\begin{tabular}{|c|c|c|c|c|c|c|c|c|}
\hline & \multicolumn{2}{|c|}{ T-1 } & \multicolumn{2}{|c|}{ T-2 } & \multicolumn{2}{|c|}{ T-3 } & \multicolumn{2}{|c|}{$\mathrm{T}-4$} \\
\hline & 2007 & 2015 & 2007 & 2015 & 2007 & 2015 & 2007 & 2015 \\
\hline $\begin{array}{l}\text { Macroinvertebrate diversity } \\
\text { (\#families/sampling unit) }\end{array}$ & 20.3 & 19.3 & $7.3^{\mathrm{a}}$ & $8.7^{\mathrm{a}}$ & $13.7^{\mathrm{a}}$ & $14.0^{\mathrm{a}}$ & 19.7 & 19.0 \\
\hline $\begin{array}{l}\text { Macroinvertebrate density } \\
\text { (individuals/sampling unit) }\end{array}$ & 492.7 & 388.3 & 487.0 & 421.3 & $828.3^{\mathrm{a}}$ & $652.0^{\mathrm{a}}$ & $1098.3^{\mathrm{a}, \mathrm{b}}$ & $732.7^{\mathrm{a}, \mathrm{b}}$ \\
\hline $\begin{array}{l}\text { Macroinvertebrate biomass } \\
\text { (mg dry-weight/sampling unit) }\end{array}$ & 476.3 & 341.7 & 615.3 & $537.0^{\mathrm{a}}$ & $896.3^{\mathrm{a}}$ & $665.3^{\mathrm{a}}$ & $970.7^{\mathrm{a}, \mathrm{b}}$ & $684.0^{\mathrm{a}, \mathrm{b}}$ \\
\hline $\begin{array}{l}\text { OC\% } \\
\text { (\%density/sampling unit) }\end{array}$ & 11.4 & 16.0 & $90.5^{\mathrm{a}}$ & $84.3^{\mathrm{a}}$ & $65.0^{\mathrm{a}}$ & $58.2^{\mathrm{a}}$ & $46.0^{\mathrm{a}}$ & $35.7^{\mathrm{a}}$ \\
\hline $\begin{array}{l}\text { ЕPT\% } \\
\text { (\%density/sampling unit) }\end{array}$ & 26.3 & 23.5 & $0.0^{\mathrm{a}}$ & $0.9^{\mathrm{a}}$ & $5.0^{\mathrm{a}}$ & $8.4^{\mathrm{a}}$ & $16.7^{\mathrm{a}}$ & 21.5 \\
\hline $\begin{array}{l}t \text {-BMWQ index } \\
\text { (index value/sampling unit) }\end{array}$ & 215.0 & 209.0 & $28.0^{\mathrm{a}, \mathrm{b}}$ & $43.7^{\mathrm{a}, \mathrm{b}}$ & $89.7^{\mathrm{a}, \mathrm{b}}$ & $112.0^{\mathrm{a}, \mathrm{b}}$ & $178.3^{\mathrm{a}}$ & $177.0^{\mathrm{a}}$ \\
\hline $\begin{array}{l}a \text {-BMWQ index } \\
\text { (index value/sampling unit) }\end{array}$ & 10.6 & 10.8 & $4.6^{\mathrm{a}, \mathrm{b}}$ & $5.7^{\mathrm{a}, \mathrm{b}}$ & $6.5^{\mathrm{a}, \mathrm{b}}$ & $8.0^{\mathrm{a}, \mathrm{b}}$ & $9.1^{\mathrm{a}}$ & $9.3^{\mathrm{a}}$ \\
\hline
\end{tabular}

${ }^{a}$ Significant $(P<0.01)$ differences between the reference station (T-1) and polluted sampling sites (T-2, T-3 and T-4) on each sampling survey are indicated with the letter a.

b Significant $(P<0.01)$ differences between sampling surveys at each sampling site are indicated with the letter $\mathrm{b}$.

Table 3. Pearson's correlation coefficients $(n=8)$ between physicochemical parameters and biological metrics and indices.

\begin{tabular}{|c|c|c|c|c|c|c|c|}
\hline & Diversity & Density & Biomass & $\mathrm{OC} \%$ & ЕРТ\% & $t$-BMWQ & $a$-BMWQ \\
\hline Water velocity & $0.924^{*}$ & 0.435 & 0.157 & $-0.839^{*}$ & 0.807 & $0.871^{*}$ & 0.830 \\
\hline Temperature & 0.529 & -0.425 & -0.683 & -0.692 & 0.683 & 0.626 & 0.705 \\
\hline $\mathrm{pH}$ & 0.738 & -0.146 & -0.417 & -0.824 & 0.794 & 0.793 & $0.856^{*}$ \\
\hline Conductivity & -0.215 & 0.598 & 0.650 & 0.491 & -0.376 & -0.334 & -0.378 \\
\hline Dissolved oxygen & $0.883^{*}$ & -0.112 & -0.429 & $-0.964^{*}$ & $0.942^{*}$ & $0.936^{*}$ & $0.967^{*}$ \\
\hline Total ammonia & -0.584 & 0.362 & 0.608 & 0.724 & -0.703 & -0.675 & -0.769 \\
\hline Phosphate & -0.721 & 0.241 & 0.534 & 0.829 & -0.817 & -0.801 & $-0.877^{*}$ \\
\hline Turbidity & $-0.839^{*}$ & -0.105 & 0.178 & $0.843^{*}$ & -0.809 & $-0.835^{*}$ & $-0.874^{*}$ \\
\hline
\end{tabular}

* Significant $(P<0.01)$ coefficients are indicated by asterisk.

these adverse and favorable effects on benthic macroinvertebrates at polluted sampling sites were less drastic in 2015 than in 2007, with mean values of macroinvertebrate diversity, EPT\% and BMWQ biotic indices being higher in 2015 than in 2007, and mean values of macroinvertebrate abundance and OC\% being lower in 2015 than in 2007 (Tab. 2). Particularly, mean values of BMWQ biotic indices ( $t$-BMWQ and $a$-BMWQ) at T-2 and T-3 were significantly $(P<0.01)$ higher in 2015 than in 2007 , and mean values of macroinvertebrate abundance (density and biomass) at T-4 were significantly $(P<0.01)$ lower in 2015 than in 2007.

Pearson's correlation coefficients between values of physicochemical parameters and values of biological metrics and indices are presented in Table 3. Dissolved oxygen showed positive and significant $(P<0.01)$ correlations with macroinvertebrate diversity, EPT\%, $t$-BMWQ and $a$-BMWQ, but negative and significant $(P<0.01)$ correlation with $\mathrm{OC} \%$ (Tab. 3). By contrast, turbidity showed negative and significant $(P<0.01)$ correlations with macroinvertebrate diversity, $t$ BMWQ and $a$-BMWQ, but positive and significant $(P<0.01)$ correlation with OC\% (Tab. 3). Besides, water velocity showed positive and significant $(P<0.01)$ correlations with macroinvertebrate diversity and $t$-BMWQ, but negative and significant $(P<0.01)$ correlation with $\mathrm{OC} \%, \mathrm{pH}$ showed positive and significant $(P<0.01)$ correlation with $a$-BMWQ, and phosphate showed negative and significant $(P<0.01)$ correlation with $a$-BMWQ (Tab. 3). Correlations involving water temperature, conductivity, total ammonia and macroinvertebrate abundance were not significant $(P>0.01)$. All in all, dissolved oxygen exhibited higher correlation coefficients than the other physicochemical parameters, and $a$-BMWQ exhibited higher correlation coefficients than the other biological metrics and indices (Tab. 3).

Mean contributions of functional feeding groups to the trophic structure of the macroinvertebrate community at each sampling site on each sampling survey are shown in Figure 2. In the 2007 and 2015 sampling surveys, shredders (Gammaridae amphipods, Leuctridae plecopterans and Sericostomatidae caddisflies) and scrapers (Baetidae and Heptageniidae ephemeropterans, Elmidae coleopterans, 


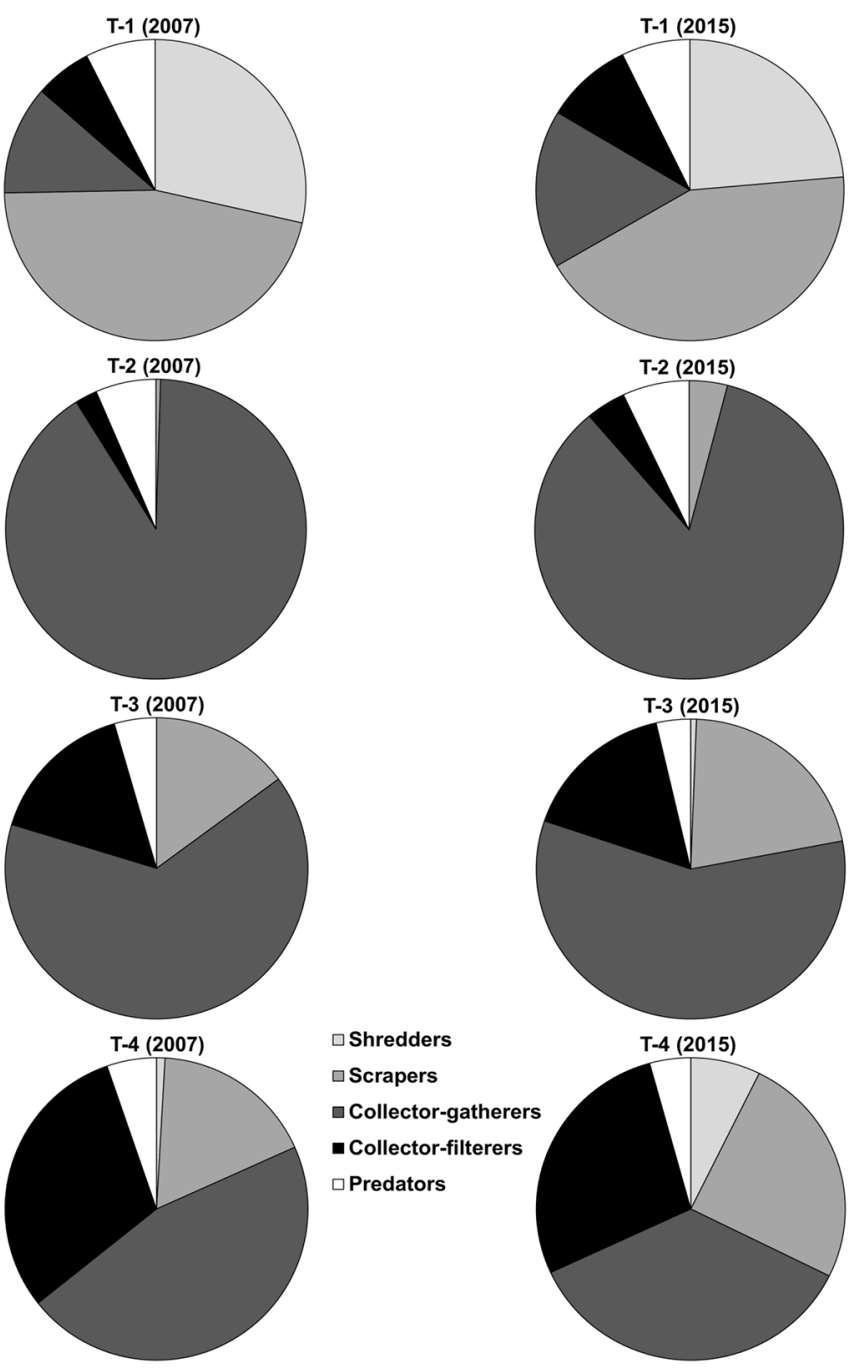

Fig. 2. Relative contributions (individuals $/ \mathrm{m}^{2}$ ) of functional feeding groups to the macroinvertebrate community at sampling sites (T-1, T2, T-3 and T-4) in the 2007 and 2015 sampling surveys.

Glossosomatidae caddisflies and Hydrobiidae snails) were the functional feeding groups most adversely affected by the trout farm effluent, particularly at T-2, whereas collectorgatherers (Tubificidae oligochaetes and Chironomidae dipterans) were the functional feeding group most favourably affected (Fig. 2). Additionally, collector-filterers (Sphaeridae bivalves, Hydropsychidae caddisflies and Simuliidae dipterans) tended to increase downstream from the trout farm outlet, particularly at T-4, with predators exhibiting the lowest mean contribution at T-3 (Fig. 2). Nonetheless, these adverse and favorable effects on functional feeding groups at polluted sampling sites were less extreme in 2015 than in 2007 (Fig. 2).

\section{Discussion}

Physicochemical alterations of rivers and streams by trout farm effluents usually involve decreases in dissolved oxygen concentrations, increases in nutrient and turbidity levels, and deposition of suspended solids on the river bottom (Boaventura et al., 1997; Bartoli et al., 2007; Ruiz-Zarzuela et al., 2009; Lalonde et al., 2015). In the present study (Tab. 1), these physicochemical alterations were more evident just below the trout farm outlet, with a clear tendency to be mitigated with increasing the downstream distance from the trout farm effluent, and also in 2007 than in 2015, as a likely consequence of decreases in the annual production of farmed rainbow trout following the 2008 economic recession (from about 35 tonnes in 2007 to less than the half in 2015). Previous studies have showed that the degree of water pollution caused by trout farm effluents on recipient rivers may be directly related to the trout farming production, although trout farm management practices, trout farm location along the river, and ecological characteristics of each recipient river may also be important factors (Boaventura et al., 1997; MacMillan et al., 2003; Sindilariu, 2007; Tello et al., 2010; Webb, 2012). Moreover, theoretical and empirical studies indicate that financial crises and economic recessions, negatively affecting production and consumption rates of material goods can result in diminished environmental pollution at different spatial and temporal scales (Siddiqi, 2000; Coondoo and Dinda, 2002; Vrekoussis et al., 2013; Tong et al., 2016).

Because values of water velocity, temperature and $\mathrm{pH}$ were within normal ranges for supporting freshwater invertebrates (Rosenberg and Resh, 1993; Tachet et al., 2003; Thorp and Covich, 2010), it seems reasonable to think that reductions in dissolved oxygen concentrations and increases in turbidity levels would be responsible, to a large extent, for the observed changes in the macroinvertebrate community downstream from the trout farm outlet (Tab. 2 and Fig. 2). Additionally, the strong siltation of suspended solids (as a sludge deposit) on the stream bottom at T-2 would be the primary environmental factor responsible for the observed changes in the macroinvertebrate community just below the trout farm outlet. Numerous field studies have already showed that oligochaetes and chironomids are the predominant benthic macroinvertebrates inhabiting organic sludge (Armitage et al., 1983; Hellawell, 1986; Rosenberg and Resh, 1993; Tachet et al., 2003; Ziglio et al., 2006; Roberts et al., 2009; Thorp and Covich, 2010; Odume et al., 2012).

The organic pollution derived from the wastewater discharge of the trout farm would also be responsible for the marked alteration in the trophic structure of the macroinvertebrate community downstream from the trout farm outlet (Fig. 2), with collector-gatherers and collectorfilterers being clearly favoured at the expense of shredders and scrapers. According to the river continuum concept (Vannote et al., 1980; Minshall et al., 1985), these changes in the macrobenthic trophic structure indicate a disruption in the functional continuity of the Upper Tajuña River. Previous studies have showed that human activities can cause multiple functional discontinuities along the longitudinal profile of river ecosystems, particularly when dam construction takes place in upper and middle reaches (Ward and Stanford, 1983; Petts et al., 1993; Wood and Armitage, 1997; Camargo et al., 2005; Bryce et al., 2010; Benitez-Mora and Camargo, 2014; Sabo et al., 2018).

Regarding the indicator performance of biological metrics and indices to assess positive responses of benthic macroinvertebrates to spatial and temporal reductions in water 
pollution downstream from the trout farm outlet, it should be evident that $\mathrm{OC} \%, \mathrm{EPT} \%, t$-BMWQ and (particularly) $a$ BMWQ exhibited better performance than macroinvertebrate abundance and diversity (Tabs. 2 and 3). These findings agree, in general, with recommendations and conclusions from other studies (Hellawell, 1986; Rosenberg and Resh, 1993; Camargo et al., 2004; Ziglio et al., 2006; Odume et al., 2012; Minoo et al., 2016). However, despite the observed positive responses of benthic macroinvertebrates, reductions in water pollution downstream from the trout farm outlet were insufficient to cease the impact caused by the trout farm on the macroinvertebrate community, since significant differences between the reference station (T-1) and polluted sampling sites (T-2, T-3 and T-4) still occurred in the 2015 sampling survey (Tab. 2 and Fig. 2). Furthermore, biological alterations at T-2 still were severe in 2015 , owing to the existence of a man-made weir upstream from T-3 (Fig. 1) that reinforced the sedimentation of suspended solids on the river bottom at T-2. In this regard, results from other studies indicate that observed poor responses of benthic macroinvertebrates to mitigation and rehabilitation measures may be due mainly to a deficient restoration of the benthic microhabitat heterogeneity (Verberk et al., 2010; Louhi et al., 2011; Verdonschot et al., 2016).

Overall, it is concluded that the wastewater treatment system of the trout farm should be improved to minimize the environmental impact on the recipient river. In addition, the sludge deposit accumulated between T-2 and T-3, as well as the man-made weir that reinforces the siltation of suspended solids on the river bottom, would have to be removed to enable the recovery of the benthic microhabitat heterogeneity and the functional river continuity.

Acknowledgements. Funds for this research came from the Spanish Ministry of Science and Innovation (Research project CGL2011-28585). The University of Alcala provided logistical support for carrying out field studies and laboratory analyses. Valuable comments by two anonymous reviewers are gratefully acknowledged.

\section{References}

Alvial IE, Tapia DH, Castro MJ, Duran BC, Verdugo CA. 2012. Analysis of benthic macroinvertebrates and biotic indices to evaluate water quality in rivers impacted by mining activities in northern Chile. Know Manag Aquat Ecosyst 407: 01.

American Public Health Association. 1998. Standard methods for the examination of water and wastewater, 20th ed. Washington DC: APHA-AWWA-WPCF, $1220 \mathrm{p}$.

Armitage PD, Moss D, Wright JF, Furse MT. 1983. The performance of a new biological water-quality score system based on macroinvertebrates over a wide-range of unpolluted running-water sites. Water Res 17: 333-347.

Bartoli M, Nizzoli D, Longhi D, Laini A, Viaroli P. 2007. Impact of a trout farm on the water quality of an Apennine creek from daily budgets of nutrients. Chem Ecol 23: 1-11.

Benitez-Mora A, Camargo JA. 2014. Ecological responses of aquatic macrophytes and benthic macroinvertebrates to dams in the Henares River Basin (Central Spain). Hydrobiologia 728: 167-178.

Boaventura R, Pedro AM, Coimbra J, Lencastre E. 1997. Trout farm effluents: Characterization and impact on the receiving streams. Environ Pollut 95: 379-387.
Bryce SA, Lomnicky GA, Kaufmann PR. 2010. Protecting sedimentsensitive aquatic species in mountain streams through the application of biologically based streambed sediment criteria. J N Am Benthol Soc 29: 657-672.

Camargo JA. 1993. Macrobenthic surveys as a valuable tool for assessing freshwater quality in the Iberian Peninsula. Environ Monit Assess 24: 71-90.

Camargo JA, Alonso A, de la Puente M. 2004. Multimetric assessment of nutrient enrichment in impounded rivers based on benthic macroinvertebrates. Environ Monit Assess 96: 233-249.

Camargo JA, Alonso A, de la Puente M. 2005. Eutrophication downstream from small reservoirs in mountain rivers of Central Spain. Water Res 39: 3376-3384.

Camargo JA, Gonzalo C, Alonso A. 2011. Assessing trout farm pollution by biological metrics and indices based on aquatic macrophytes and benthic macroinvertebrates: A case study. Ecol Indic 11: 911-917.

Carr OJ, Goulder R. 1990. Fish farm effluents in rivers: Effects on inorganic nutrients, algae and the macrophyte Ranunculus penicillatus. Water Res 24: 639-647.

Coondoo D, Dinda S. 2002. Causality between income and emission: A country group-specific econometric analysis. Ecol Econ 40: 351-367.

Emerson K, Russo RC, Lund RE, Thurston RV. 1975. Aqueous ammonia equilibrium calculations: Effect of $\mathrm{pH}$ and temperature. $J$ Fish Res Board Can 32: 2379-2383.

Food and Agricultural Organization of the United Nations. 2016. Fishery and Aquaculture Statistics: 2014 Yearbook. Rome: Fisheries and Aquaculture Department, Food and Agricultural Organization of the United Nations.

Gartzia De Bikuña B, López E, Leonardo JM, Arrate J, Martínez A, Agirre A, Manzanos A. 2015. Reduction of sampling effort assessing macroinvertebrate-assemblages for biomonitoring of rivers. Knowl Manag Aquat Ecosyst 416, 08.

Hauer FR, Lamberti GA, eds. 1996. Methods in stream ecology. San Diego (CA): Academic Press, 696 p.

Hellawell JM. 1986. Biological indicators of freshwater pollution and environmental management. London: Elsevier Applied Science Publishers, $518 \mathrm{p}$.

Lalonde BA, Ernst W, Garron C. 2015. Chemical and physical characterisation of effluents from land-based fish farms in Atlantic Canada. Aquacult Int 23: 535-546.

Louhi P, Mykra H, Paavola R, Huusko A, Vehanen T, Maki-Petays A, Muotka T. 2011. Twenty years of stream restoration in Finland: Little response by benthic macroinvertebrate communities. Ecol Appl 21: 1950-1961.

MacMillan JR, Huddleston T, Wooley M, Fothergill K. 2003. Best management practice development to minimize environmental impacts from large flow-through trout farms. Aquaculture 226: 91-99.

Ministerio de Agricultura, Pesca y Alimentación. 2018. Producción Nacional de Acuicultura. Gobierno de España: Ministerio de Agricultura, Pesca y Alimentación. www.mapa.gob.es.

Minoo CM, Ngugi CC, Oyoo-Okoth E, Muthumbi A, Sigana D, Mulwa R, Chemoiwa EJ. 2016. Monitoring the effects of aquaculture effluents on benthic macroinvertebrate populations and functional feeding responses in a tropical highland headwater stream (Kenya). Aquat Ecosyst Health Manag 19: 431-440.

Minshall GW, Cummins KW, Petersen RC, Cushing CE, Bruns DA, Sedell JR, Vannote RL. 1985. Developments in stream ecosystem theory. Can J Fish Aquat Sci 42: 1045-1055.

Odume ON, Muller WJ, Arimoro FO, Palmer CG. 2012. The impact of water quality deterioration on macroinvertebrate communities in 
the Swartkops River, South Africa: A multimetric approach. African J Aquat Sci 37: 191-200.

Petts GE, Armitage PD, Castella E. 1993. Macroinvertebrate response to river regulation: The River Rede, UK. Regul Rivers Res Manage 8: $167-178$.

Roberts L, Boardman G, Voshell R. 2009. Benthic macroinvertebrate susceptibility to trout farm effluents. Water Environ Res 81: 150 159.

Rosenberg DM, Resh VH, eds. 1993. Freshwater biomonitoring and benthic macroinvertebrates. London: Chapman and Hall, $488 \mathrm{p}$.

Ruiz-Zarzuela I, Halaihel N, Balcázar JL, Ortega C, Vendrell D, Pérez T, Alonso JL, de Blas I. 2009. Effect of fish farming on the water quality of rivers in northeast Spain. WST 60: 663-671.

Sabo JL, Caron M, Doucett R, Dibble KL, Ruhi A, Marks JC, Hungate BA, Kennedy TA. 2018. Pulsed flows, tributary inputs and food-web structure in a highly regulated river. $J$ Appl Ecol 55: 1884-1895.

Siddiqi TA. 2000. The Asian financial crisis: Is it good for the global environment? Global Environ Change 10: 1-7.

Sindilariu P-D. 2007. Reduction in effluent nutrient loads from flowthrough facilities for trout production: A review. Aquacult Res 38: $1005-1036$

Sokal RR, Rohlf FJ. 1995. Biometry: The principles and practice of statistics in biological research, 3rd ed. New York: Freeman, $887 \mathrm{p}$.

Tachet H, Richoux P, Bournaud M, Usseglio-Polatera P. 2003. Invertebrés d'eau douce (Systematique, Biologie, Écologie). Paris: CNRS Éditions, $587 \mathrm{p}$.

Tello A, Corner RA, Tefler TC. 2010. How do land-based salmonids farms affect stream ecology? Environ Pollut 158: 1147-1158.

Thorp JH, Covich AP, eds. 2010. Ecology and classification of North American freshwater invertebrates, 3rd ed. San Diego (CA): Academic Press, $1021 \mathrm{p}$.

Tong D, Pan L, Chen W, Lamsal L, Lee P, Tang Y, Kim H, Kondragunta S, Stajner I. 2016. Impact of the 2008 global recession on air quality over the United States: Implications for surface ozone levels from changes in NOx emissions. Geophys Res Lett 43: 9280 9288.

US Environmental Protection Agency. 2013. Aquatic life ambient water quality criteria for ammonia - freshwater. Washington DC: US EPA 822-R-13-001, Office of Water, Office of Science and Technology, $242 \mathrm{p}$.

Vannote RL, Minshall CW, Cummins KW, Sedell JR, Cushing CE. 1980. The river continuum concept. Can J Fish Aquat Sci 37: 130-137.

Verberk WCEP, Leuven RSEW, van Duinen GA, Esselink H. 2010. Loss of environmental heterogeneity and aquatic macroinvertebrate diversity following large-scale restoration management. Basic Appl Ecol 11: 440-449.

Verdonschot RCM, Kail J, McKie BG, Verdonschot PFM. 2016. The role of benthic microhabitats in determining the effects of hydromorphological river restoration on macroinvertebrates. Hydrobiologia 769: 55-66.

Villanueva VD, Queimalinos C, Modenutti B, Ayala J. 2000. Effects of fish farm effluents on the periphyton of an Andean stream. Arch Fish Mar Res 48: 283-294.

Vrekoussis M, Richter A, Hilboll A, Burrows JP, Gerasopoulos E, Lelieveld J, Barrie L, Zerefos C, Mihalopoulos N. 2013. Economic crisis detected from space: Air quality observations over Athens. Geophys Res Lett 40: 458-463.

Ward JV, Stanford JA. 1983. The serial discontinuity concept of lotic ecosystems. In: Fontane TD, Bartell SM, eds. Dynamics of lotic ecosystems. Ann Arbor (MI): Ann Arbor Science Publishers, pp. 29-42.

Webb JA. 2012. Effects of trout farms on stream macroinvertebrates: Linking farm-scale disturbance to ecological impact. Aquacult Environ Interac 3: 23-32.

Wood PJ, Armitage PD. 1997. Biological effects of fine sediment in the lotic environment. Environ Manage 21: 203-217.

Ziglio G, Siligardi M, Flaim G, eds. 2006. Biological monitoring of rivers. Chichester: Wiley, $485 \mathrm{p}$.

Cite this article as: Camargo JA. 2019. Positive responses of benthic macroinvertebrates to spatial and temporal reductions in water pollution downstream from a trout farm outlet. Knowl. Manag. Aquat. Ecosyst., 420, 16. 